\title{
Música fácil. Manual didáctico de Lenguaje Musical. Un método
}

directo y

sencillo para

iniciarse en el mundo de la música.
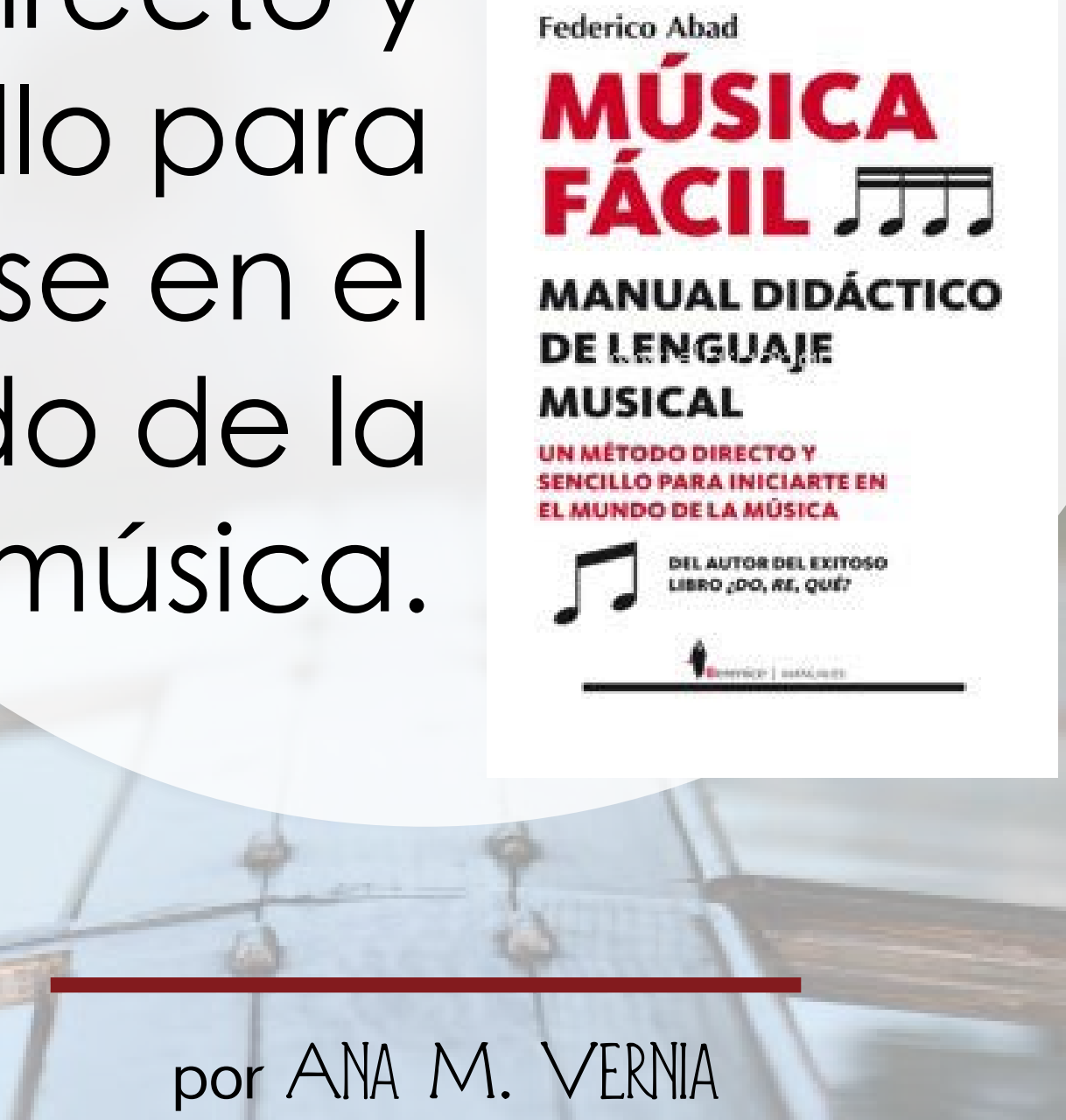

Universitat Jaume I (Castellón)
Autores: Federico Abad

Editorial: Berenice, Editorial

Año de la edición: 2018

Colección: Manuales

Encuadernación: Rústica con solapas
Formato: $17 \times 24$

Páginas: 288

Idiomas: Castellano

Tipo: Libro

ISBN: 978-84-16920-08-2

Federico Abad, profesor de secundaria y bachillerato, es un apasionado de la música y la docencia. Titulado superior en pedagogía musical y diplomado en profesorado de EGB por ciencias humanas. Su interés en acercar la música a su alumnado, le ha llevado a la escritura de libros, cuyo estudio permite acercar tanto a su alumnado como a cualquier persona, melómana, amateur o simplemente, con interés de aprender música, a cualquier edad. Así es este nuevo libro, repartido en diferentes y variados capítulos y apartados que van del sonido al ritmo, pasando por el ruido, el silencio, la intensidad, el pulso, las figuras o los silencios, hasta llegar a la dificultad de los acordes. Pero no olvida, como decente que es, la importancia de acompañar a los lectores, minimizando dificultades, detallando cada epígrafe y acompañando, con claras ilustraciones y ejemplos para permitir una mejor comprensión.

Sin duda, un libro que convierte la enseñanza musical, en lo que debería ser. Aprendizaje fácil, sencillo, ilusionante y comprensivo. Alejándose de los aburridos métodos poco didácticos, que enredaban con sus explicaciones y complejos ejemplos.

Destacamos el capítulo que dedica a la melodía y a la expresión musical, cuya lectura nos acerca a los grandes pedagogos, pero con una visión más actual y más real, atendiendo tanto a los contenidos que hoy podemos encontrar en las clases de primaria o secundaria, y también a los conservatorios y escuelas de música. 